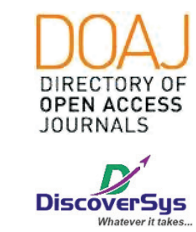

Published by DiscoverSys

\section{Uji efektivitas ekstrak etanol air kelopak bunga Hibiscus sabdariffa linn terhadap profil lipid tikus hiperlipidemia}

\author{
Ode Mahesa Putra, ${ }^{1 *}$ I Made Jawi, ${ }^{2}$ Bagus Komang Satriyasa ${ }^{2}$
}

\section{ABSTRACT}

Introduction: Cardiovascular disease is still the biggest cause of death in the world. Many factors that play a role in the development of this disease, one of them is Hiperlipidemia. The situation can be handled using conventional medicines, but there are concerns about the side effects of conventional medicines. Hibiscus Sabdariffa L. (roselle) is rich in polyphenols, anthocyanins, flavonoids which can be used as drugs for the prevention of cardiovascular diseases that have biological activities such as antihypertensive, antimutagenic, chemopreventive, antioxidant, anticonvulsant, anxiogenic, CNSdepressant, serotoninergic activity, reducing damage from oxidative liver, anti-inflammatory and hypoglycemic activity. This study aims to evaluate the effects of roselle ethanol extract as a hypolipidemic agent.

Method: This study used an experimental design, using wistar mouse divided into five groups: (1 received aquadest intervention, C2 (simvastatin $0.2 \mathrm{~g} / \mathrm{kg} / \mathrm{day}$ ), 11 (100mg / kg / day roselle extract),
12 (200 mg / kg / day roselle extract), and I3 (300 mg / kg / day roselle extract) mice was given hypercholesterol oil feed for two weeks preceeding drugs intervention, then intervention was given for eight weeks and analyzed on mouse lipid profile component.

Result: There were significant differences in total cholesterol, triglyceride, LDL, and HDL values among the intervention groups $(p=0.000)$. The lowest total cholesterol belonging to the $C 2$ group $(117.83 \pm 6.36)$ was followed by $13(143.66 \pm 11.75)$, the lowest triglyceride belonging to the $\mathrm{C} 2$ group $(284.83 \pm 7.46)$ was followed by $13(306.84 \pm 8.61)$, the lowest LDL was owned by the group C2 (104.50 \pm 4.37), followed by $13(120.50 \pm 2.42)$, the highest HDL belonging to the C2 group ( $44.80 \pm 3.16$ followed by 13 group $(38.02 \pm 3.40)$.

Conclusion: The ethanol extract at $300 \mathrm{mg} / \mathrm{kg} /$ day gave better improvement of lipid profile rather than roselle ethanol extract $100 \mathrm{mg}$ / kg / day, $200 \mathrm{mg} / \mathrm{kg} /$ day, and aquadest control, but still not able to provide better improvement than simvastatin.

Keywords: roselle ethanol extract, lipid profile, simvastatin

Cite This Article: Putra, 0.M., Jawi, I.M., Satriyasa, B.K. 2019. Uji efektivitas ekstrak etanol air kelopak bunga Hibiscus sabdariffa linn terhadap profil lipid tikus hiperlipidemia. Intisari Sains Medis 10(2): 273-278. D0I: 10.15562/ism.v10i2.189

\title{
ABSTRAK
}

Latar Belakang: Penyakit kardiovaskuler masih menjadi penyebab kematian terbesar di dunia. Banyak factor yang ikut berperan dalam perkembangan dari penyakit ini, salah satunya adalah Hiperlipidemia. Keadaan tersebut dapat ditangani dengan menggunakan obat-obatan konvensional, namun terdapat kekhawatiran tentang efek samping obat-obatan konvensional. Hibiscus Sabdariffa L. (roselle) kaya polifenol, antosianin, flavonoid dimana dapat digunakan sebagai obat untuk pencegahan penyakit kardiovaskular yang memiliki aktivitas biologis seperti antihipertensi, antimutagenik, kemopreventif, antioksidan, antikonvulsan, anxiogenik, CNS-depresan, aktivitas serotoninergik, mengurangi kerusakan dari oksidatif hati, anti-inflamasi dan aktivitas hipoglikemik. Studi ini bertujuan untuk melakukan evaluasi efek dari ekstrak etanol roselle sebagai agen hipolipidemia.

Metode: Studi ini menggunaan rancangan eksperimental, menggunakan hewan coba tikus wistar yang dibagi menjadi lima kelompok yaitu C1 mendapat intervensi aquadest, C2 (simvastatin 0,2g/kg/hari) I1 (ektrak rosela 100mg/kg/hari), I2 (200 mg/kg/hari), 13 (300 mg/kg/hari) tikus diberikan pakan minyak hiperkolesterol selama dua minggu, kemudian intervensi diberikan selama delapan minggu dan dilakukan analisis pada komponen profil lipid tikus.

Hasil: Terdapat perbedaan yang bermakna pada nilai kolesterol total, trigiliserida, $L D L$, dan HDL diantara kelompok intervensi $(p=0,000)$. Kolesterol total paling rendah dimiliki oleh kelompok C2 $(117,83 \pm 6,36)$ kemudian disusul oleh $13(143,66 \pm 11,75)$, trigliserida terendah dimiliki oleh kelompok C2 $(284,83 \pm 7,46)$ kemudian disusul oleh I3 $(306,84 \pm$ $8,61)$, nilai LDL terendah dimiliki oleh kelompok C2 $(104,50 \pm 4,37)$ disusul oleh $\mathrm{B} 3(120,50 \pm 2,42)$, HDL tertinggi dimiliki oleh kelompok C2 $(44,80 \pm 3,16)$ disusul oleh kelompok $13(38,02 \pm 3,40)$.

Simpulan: Ekstrak etanol dosis $300 \mathrm{mg} / \mathrm{kg} / \mathrm{hari}$ memberikan perbaikan profil lipid lebih baik dibandingkan dengan ekstrak ethanol $100 \mathrm{mg} / \mathrm{kg} / \mathrm{hari}$ dan $200 \mathrm{mg} / \mathrm{kg} / \mathrm{hari}$, namun masih belum mampu memberikan perbaikan lebih baik dari simvastatin. 


\section{PENDAHULUAN}

Penyakit kardiovaskuler masih menjadi penyebab kematian terbesar di dunia. Jenis penyakit kardiovaskuler yang merupakan penyebab kematian utama di dunia adalah penyakit jantung koroner (Mảrufi et al. 2014). Data tahun 2012 dari World Health Organiation (WHO) menunjukkan bahwa penyakit jantung koroner dan stroke menyebabkan 14,1 juta kematian di seluruh dunia. Di Indonesia, prevalensi dari penyakit stroke berdasarkan riset kesehatan dasar (Riskesdas) pada tahun 2007 adalah delapan per seribu penduduk atau sebesar $0,8 \%$. Sedangkan untuk penyakit jantung coroner berdasarkan riset kesehatan dasar (Riskesdas) tahun 2013 angka prevalensinya adalah sebesar $1,5 \% .{ }^{1}$

Banyak faktor yang ikut berperan dalam perkembangan dari penyakit ini, salah satunya adalah Hiperlipidemia. Hiperlipidemia merupakan suatu keadaan tingginya kadar lipid yang ditandai dengan meningkatnya kadar trigliserida, LDL (low density lipoprotein), dan kolesterol darah melebihi batas normal (pada manusia > $200 \mathrm{mg} / \mathrm{dl})^{3}{ }^{3}$ Banyak faktor yang dapat menyebabkan hyperlipidemia, yaitu seperti pola makan kaya lemak jenuh dan kolesterol, usia, keluarga, hipertensi dan gaya hidup merupakan penyebab tersering dalam peningkatan kadar kolesterol dan kadar LDL, dimana merupakan penyebab timbulnya aterosklerosis dan penyakit jantung koroner. ${ }^{2}$ kolesterol LDL berlebih dapat menyebabkan penyumbatan arteri, yang akhirnya menyebabkan serangan jantung. studi populasi jelas telah menunjukkan bahwa semakin tinggi tingkat kolesterol LDL, semakin besar risiko penyakit jantung. Oleh karena itu, kolesterol LDL dikenal sebagai kolesterol jahat. Sebaliknya semakin rendah tingkat kolesterol HDL, semakin besar risiko penyakit jantung koroner. Akibatnya, kolesterol HDL sering disebut sebagai kolesterol baik. kadar kolesterol HDL yang rendah biasanya disertai dengan peningkatan kadar trigliserida darah., ${ }^{4,12}$

Kondisi hiperlipidemia ini dapat diturunkan dengan menggunakan obat-obatan. Obat-obatan konvensional tersebut antara lain golongan asam fibrat, resin, penghambat HMG CoA reduktase (statin), dan asam nikotinat (niasin). Namun terdapat kekhawatiran tentang efek samping obatobatan konvensional tersebut seperti peningkatan enzim hati, gejala gastrointestinal, kecenderungan untuk cholelithiasis, rhabdomyelosis, miopati, disfungsi ginjal. $^{5}$ studi lainnya menunjukkan efektivitas obat-obatan herbal dapat mengobati kondisi dislipidemia dimana terdapat bahan bahan dari tanaman herbal yang aman seperti serat makanan, vitamin, flavonoid, estrols, polifenol, senyawa antioksidan. Meskipun efek samping yg disebabkan ini lebih rendah dari pada obat konvensial, penggunaannya dalam tahap primer dari dislipidemia dan aterosklerosis tampaknya rasional. ${ }^{5}$ Salah satu tumbuhan yang dipercaya dapat menurunkan kolesterol adalah rosella (Hibiscus sabdariffa L.) baik pada bagian kelopak bunga dan daunnya. ${ }^{3}$

Hibiscus sabdariffa L. [Roselle] merupakan tanaman yang termasuk dalam keluarga Malvaceae dan secara luas dibudidayakan di daerah tropis daerah seperti Karibia, Australia, Brazil, Amerika Tengah, India, Afrika, Amerika dan Filipina. ${ }^{5}$ Secara tradisional, bunga dan daun telah digunakan sebagai minuman dimana dipercaya sebagai obat untuk penyakit jantung dan saraf, sebagai pencahar, untuk mengurangi berat badan, sebagai diuretik, untuk mengaktifkan dan menetralisir sekresi hati, untuk mengaktifkan bagian lambung sebagai pencernaan, untuk arteriosclerosis, sebagai antiseptik, meredakan batuk kering, mengobati sakit kulit, kanker, dan menurunkan kadar kolesterol dan tekanan darah. ${ }^{5}$

Hibiscus Sabdariffa L. kaya polifenol, antosianin, flavonoid dimana dapat digunakan sebagai obat untuk pencegahan penyakit kardiovaskular. ${ }^{5}$ Hibiscus sabdariffa L. Juga memiliki aktivitas biologis seperti antihipertensi, antimutagenik, kemopreventif, antioksidan, antikonvulsan, anxiogenic, CNS-depressan, aktivitas serotoninergic, mengurangi kerusakan dari oksidatif hati, anti-inflamasi dan aktivitas hipoglikemik. ${ }^{2}$

Berdasarkan penelitian sebelumnya yang dilakukan oleh Gosain et al. tahun 2010, tikus yang mengalami hiperlipidemia diberikan ekstrak etanol dari daun H. sabdariffa dengan tiga dosis (100, $200,300 \mathrm{mg} / \mathrm{kg} / \mathrm{hari}$ ) secara oral dengan induksi kolesterol $(2 \mathrm{~g} / \mathrm{kg} / \mathrm{hari})$ secara oral. Dengan obat pembanding adalah Atorvastatin $(10 \mathrm{mg} / \mathrm{kg} / \mathrm{hari})$ diberikan oral. Pada penelitian itu didapat bahwa pada dosis $200 \mathrm{mg} / \mathrm{kg} / \mathrm{hari}$ dan $300 \mathrm{mg} / \mathrm{kg} / \mathrm{hari}$ terjadi penurunan yang signifikan pada kadar kolesterol serum sebanyak 18.5\% dan 22\%.5 Penurunan juga terjadi pada kadar trigliserida serum sebanyak $15.6 \%$ dan $20.6 \%$, LDL serum sebanyak $24 \%$ dan $30 \%$, juga VLDL serum sebanyak $15.5 \%$ dan $20.5 \%$, seluruhnya bila dibandingkan dengan kelompok yang diinduksi kolesterol. Pada dosis 300mg/kg/ hari diketahui bahwa dosis tersebut aman dan merupakan dosis yang paling efektif. Dalam penelitian tersebut peneliti menggunakan ekstrak etanol dari daun $H$. sabdariffa dengan tiga dosis $(100,200$, $300 \mathrm{mg} / \mathrm{kg} / \mathrm{hari})^{2}$

Berdasarkan latar belakang di atas pengujian efektivitas ekstrak etanol air kelopak bunga Hibiscus sabdariffa atau rosella dimana dilakukan terhadap tikus hiperlipidemia dengan menggunakan acuan dosis dari penelitian Gosain 
(2010) yaitu $100 \mathrm{mg} / \mathrm{kg} / \mathrm{hari}, 200 \mathrm{mg} / \mathrm{kg} / \mathrm{hari}$, dan $300 \mathrm{mg} / \mathrm{kg} / \mathrm{hari}$, maka dilakukan penelitian dengan melibatkan tikus yang diberi pakan kaya lemak.

\section{METODE}

Penelitian ini menggunakan rancangan post test eksperimental yang diterapkan pada tikus wistar yang diberikan pakan hiperkolesterol. Tikus kemudian dibagi menjadi lima kelompok intervensi. Kelompok kontrol mendapatkan intervensi aquades, kelompok $\mathrm{C} 2$ mendapat simvastatin $0,2 \mathrm{mg} / \mathrm{kg}$, kelompok I1 mendapat intervensi ekstrak rosela $100 \mathrm{mg} / \mathrm{kg} / \mathrm{hari}$, kelompok I2 mendapatkan intervensi ekstrak rosela $200 \mathrm{mg} / \mathrm{kg} / \mathrm{hari}$, dan kelompok I3 mendapatkan intervensi ekstrak rosela $300 \mathrm{mg} / \mathrm{kg} / \mathrm{hari}$. Intervensi dilakukan selama delapan minggu, kemudian dilakukan analisis terhadap profil lipid dari tikus (total kolesterol, kolesterol HDL, kolesterol LDL, dan trigliserida). Analisis One- Way ANOVA digunakan untuk melihat perbedaan antar kelompok intervensi, kemudian dilanjutkan dengan analisis post hoct. Pemeliharaan tikus dilakukan di Laboratorium Farmakologi Fakultas Kedokteran Universitas Udayana, sebelum dilakukan intervensi, tikus diberikan kesempatan adaptasi berupa siklus terang gelap selama satu minggu.

\section{HASIL PENELITIAN}

Penelitian ini menggunakan post-test experimental terhadap 30 tikus wistar yang terbagi dalam lima kelompok intervensi, untuk menguji ekstrak rosela $100 \mathrm{mg} / \mathrm{kg} / \mathrm{hari}$ (I1), 200mg/kg/hari (I2), dan $300 \mathrm{mg} / \mathrm{kg} / \mathrm{hari}$ (I3) yang dibandingkan dengan plasebo yang mengandung aquadest $(\mathrm{C} 1)$ dan obat simvastatin $0.2 \mathrm{mg}(\mathrm{C} 2)$ terhadap penurunan kadar trigliserida, kolesterol total, dan LDL. Analisis perbandingan profil lipid antar kelompok intervensi dapat dilihat pada tabel 1 .

Berdasarkan analisis kadar kolesterol total, pada kelompok C1 dengan rerata $215.16 \pm 15.95$, kemudian pada kelompok C2 dengan rerata $117.83 \pm$ 6.36 , kemudian pada kelompok I1 dengan rerata $206.33 \pm 8.01$, pada kelompok I2 dengan rerata $177.50 \pm 4.23$, pada kelompok I3 dengan rerata $143.66 \pm 11.75$. Melalui analisis ANOVA menunjukkan terdapat perbedaan diantara kelompok intervensi $(\mathrm{p}=0.000)$. (tabel 1$)$

Berdasarkan analisis kadar kolesterol trigliserida, kelompok $\mathrm{C} 1$ dengan rerata $395.33 \pm$ 22.83 , kemudian pada kelompok C2 dengan rerata $284.83 \pm 7.46$, kemudian pada kelompok I1 dengan rerata $385.66 \pm 11.29$, pada kelompok I2 dengan rerata $347.83 \pm 22.05$, pada kelompok I3 dengan rerata $306.84 \pm 8.61$. Melalui analisis ANOVA menunjukkan terdapat perbedaan diantara kelompok intervensi $(\mathrm{p}=0.000)$. (tabel 1$)$

Berdasarkan analisis kadar kolesterol LDL, kelompok C1 dengan rerata $141.16 \pm 4.02$, kemudian pada kelompok C2 dengan rerata $104.50 \pm$ 4.37, kemudian pada kelompok I1 dengan rerata $139.83 \pm 4.87$, pada kelompok I2 dengan rerata $138.16 \pm 2.48$, pada kelompok I3 dengan rerata $120.50 \pm 2.42$. Melalui analisis ANOVA menunjukkan terdapat perbedaan diantara kelompok intervensi $(p=0.000)$. (tabel 1$)$

Berdasarkan analisis kadar kolesterol HDL, kelompok $\mathrm{C} 1$ dengan rerata $20.16 \pm 1.94$, kemudian pada kelompok C2 dengan rerata $44.80 \pm 3.16$, kemudian pada kelompok I1 dengan rerata $20.83 \pm$ 1.94, pada kelompok 12 dengan rerata $30.34 \pm 2.25$, pada kelompok I3 dengan rerata $38.02 \pm 3.40$. Melalui analisis ANOVA menunjukkan terdapat perbedaan diantara kelompok intervensi $(\mathrm{p}=$ 0.000). (tabel 1)

Analisis post-hoc bertujuan untuk mencari perbedaan pada masing-masing kelompok intervensi secara berpasangan guna membandingkan efek intervensi pemberian rosela terhadap obat simvastatin dan aquadest. Analisis post-hoc profil lipid dapat dilihat pada grafik 1 .

Melalui analisis post hoc, tidak terdapat perbedaan yang bermakna pada kadar kolesterol total antara kelompok kontrol C1 dengan I1 ( $\mathrm{p}>0.05)$. Terdapat perbedaan yang bermakna antara CI dengan $\mathrm{C} 2$, I2, dan I3 $(\mathrm{p}<0.05)$. Hasil analisis beda rerata adalah: $\mathrm{C} 1$ vs $\mathrm{C} 2, \mathrm{p}=0.000$. $\mathrm{C} 1$ vs $\mathrm{I} 1, \mathrm{p}=0.114$. $\mathrm{C} 1$ vs $\mathrm{I} 2, \mathrm{p}=0.000$. $\mathrm{C} 1$ vs $\mathrm{I} 3, \mathrm{p}=0.000$. C 2 vs $\mathrm{I} 1$, $\mathrm{p}=0.000$. C2 vs I2, $\mathrm{p}=0.000$. C2 vs $\mathrm{I} 3, \mathrm{p}=0.024$. I1 vs I2, $p=0.000$. I1 vs I3, $p=0.000$. I2 vs I3, $p=0.000$.

Tidak terdapat perbedaan yang bermakna pada kadar trigliserida antara kelompok kontrol C1 dengan I1 ( $\mathrm{p}>0.05)$. Terdapat perbedaan yang bermakna antara CI dengan C2, I2, dan I3 ( $\mathrm{p}<0.05)$. Hasil analisis beda rerata adalah: $\mathrm{C} 1$ vs $\mathrm{C} 2, \mathrm{p}=0.000$. $\mathrm{C} 1$ vs $\mathrm{I} 1, \mathrm{p}=0.303$. $\mathrm{C} 1$ vs $\mathrm{I} 2, \mathrm{p}=0.000 . \mathrm{C} 1$ vs $\mathrm{I} 3$, $\mathrm{p}=0.000$. C2 vs I1, $\mathrm{p}=0.000$. C2 vs $\mathrm{I} 2, \mathrm{p}=0.000$. C2 vs $I 3, p=0.026$. I1 vs $I 2, p=0.000$. I1 vs $I 3, p=0.000$. I 2 vs I $3, p=0.000$.

Tidak terdapat perbedaan yang bermakna pada kadar kolesterol LDL antara kelompok kontrol C1 dengan I1 ( $p>0.05)$, C1 dan I2 ( $>>0.05)$, dan I1 dan I2 $(p>0.05)$. Terdapat perbedaan yang bermakna antara CI dengan $\mathrm{C} 2$ dan $\mathrm{I} 3(\mathrm{p}<0.05)$. Hasil analisis beda rerata adalah: $\mathrm{C} 1$ vs $\mathrm{C} 2, \mathrm{p}=0.000$. $\mathrm{C} 1$ vs $\mathrm{I} 1$, $p=0.546$. $C 1$ vs $I 2, p=0.180$. $C 1$ vs $I 3, p=0.000$. $C 2$ vs $\mathrm{I} 1, \mathrm{p}=0.000$. C2 vs I2, $\mathrm{p}=0.000$. C2 vs I3, $\mathrm{p}=0.000$. I1 vs $\mathrm{I} 2, \mathrm{p}=0.451$. I1 vs $\mathrm{I} 3, \mathrm{p}=0.000$. I 2 vs $\mathrm{I} 3, \mathrm{p}=0.000$.

Tidak terdapat perbedaan yang bermakna pada kadar kolesterol HDL antara kelompok kontrol $\mathrm{C} 1$ dengan I1 ( $>0.05)$. Terdapat perbedaan yang bermakna antara CI dengan C2, I2, dan I3 ( $\mathrm{p}<0.05)$. 
Tabel 1 Perbedaan profil lipid pada kelima kelompok intervensi

\begin{tabular}{|c|c|c|c|c|}
\hline Kelompok intervensi & $\mathbf{N}$ & Rerata \pm SD & $\mathbf{F}$ & Nilai $p$ \\
\hline \multicolumn{5}{|l|}{ Kolesterol total } \\
\hline $\mathrm{C} 1$ & 6 & $215.16 \pm 15.95$ & \multirow{5}{*}{99.05} & \multirow{5}{*}{$0.000^{\star}$} \\
\hline $\mathrm{C} 2$ & 6 & $117.83 \pm 6.36$ & & \\
\hline I1 & 6 & $206.33 \pm 8.01$ & & \\
\hline $\mathrm{I} 2$ & 6 & $177.50 \pm 4.23$ & & \\
\hline I3 & 6 & $143.66 \pm 11.75$ & & \\
\hline \multicolumn{5}{|l|}{ Trigliserida } \\
\hline $\mathrm{C} 1$ & 6 & $395.33 \pm 22.83$ & \multirow{5}{*}{54.92} & \multirow{5}{*}{$0.000^{\star}$} \\
\hline $\mathrm{C} 2$ & 6 & $284.83 \pm 7.46$ & & \\
\hline I1 & 6 & $385.66 \pm 11.29$ & & \\
\hline $\mathrm{I} 2$ & 6 & $347.83 \pm 22.05$ & & \\
\hline $\mathrm{I} 3$ & 6 & $306.84 \pm 8.61$ & & \\
\hline \multicolumn{5}{|l|}{ LDL kolesterol } \\
\hline $\mathrm{C} 1$ & 6 & $141.16 \pm 4.02$ & \multirow{5}{*}{107.78} & \multirow{5}{*}{$0.000^{*}$} \\
\hline $\mathrm{C} 2$ & 6 & $104.50 \pm 4.37$ & & \\
\hline I1 & 6 & $139.83 \pm 4.87$ & & \\
\hline $\mathrm{I} 2$ & 6 & $138.16 \pm 2.48$ & & \\
\hline $\mathrm{I} 3$ & 6 & $120.50 \pm 2.42$ & & \\
\hline \multicolumn{5}{|l|}{ HDL kolesterol } \\
\hline $\mathrm{C} 1$ & 6 & $20.16 \pm 1.94$ & \multirow{5}{*}{96.18} & \multirow{5}{*}{$0.000^{*}$} \\
\hline $\mathrm{C} 2$ & 6 & $44.80 \pm 3.16$ & & \\
\hline I1 & 6 & $20.83 \pm 1.94$ & & \\
\hline $\mathrm{I} 2$ & 6 & $30.34 \pm 2.25$ & & \\
\hline $\mathrm{I} 3$ & 6 & $38.02 \pm 3.40$ & & \\
\hline
\end{tabular}

${ }^{*}$ signifikan ( $\left.p<0.05\right), C 1$ mendapat aquadest, C2 mendapat simvastatin $0.2 \mathrm{mg}$, I1 mendapat ekstrak rosela $100 \mathrm{mg} / \mathrm{kg} / \mathrm{hari}$, I2 mendapat ekstrak rosela $200 \mathrm{mg} / \mathrm{kg} / \mathrm{hari}$, I3 mendapat ekstrak rosela $300 \mathrm{mg} / \mathrm{kg} / \mathrm{hari}$.

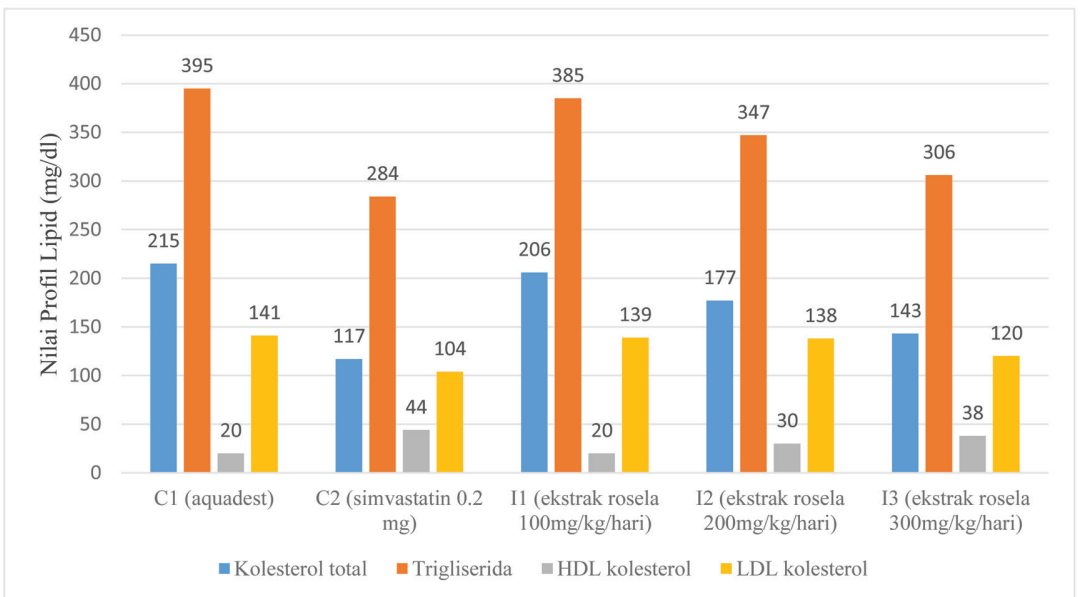

Grafik 1 Rerata profil lipid pada setiap kelompok intervensi

Hasil analisis beda rerata adalah: $\mathrm{C} 1$ vs $\mathrm{C} 2, \mathrm{p}=0.000$. C1 vs I1, $\mathrm{p}=0.663$. C1 vs $\mathrm{I} 2, \mathrm{p}=0.000$. C1 vs $\mathrm{I} 3$, $\mathrm{p}=0.000$. C2 vs $\mathrm{I} 1, \mathrm{p}=0.000$. C2 vs $\mathrm{I} 2, \mathrm{p}=0.000$. C2 vs $\mathrm{I} 3, \mathrm{p}=0.001$. I1 vs $\mathrm{I} 2, \mathrm{p}=0.000$. I1 vs $\mathrm{I} 3, \mathrm{p}=0.000$. $\mathrm{I} 2$ vs $\mathrm{I} 3, \mathrm{p}=0.000$.

\section{PEMBAHASAN}

Penelitian ini mengkaji mengenai pemberian eksrak rosela yang mengandung flavonoid dan antosianin terhadap perubahan profil lipid (kolesterol total, LDL, trigliserida, dan HDL) yang dibandingkan dengan kontrol negative (aquadest) dan kontrol positif (simvastatin $0.2 \mathrm{mg}$ ) pada tikus yang mengalami dyslipidemia.

Hasil penelitian ini menunjukkan melalui analisis uji ANOVA kelompok kontrol positif memberikan perubahan profil lipid yang terbaik, kemudian disusul oleh kelompok intervensi ekstrak rosela $300 \mathrm{mg} / \mathrm{kg} / \mathrm{hari}$. Serta pemberian ekstrak rosela $100 \mathrm{mg} / \mathrm{kg} / \mathrm{hari}$ tidak menunjukkan perbedaan yang bermakna dengan kelompok kontrol negative (aquadest).

Ekstrak rosela merupakan suatu senyawa yang mengandung antosianin dan merupakan senyawa yang termasuk dalam golongan isovlavon. Pemberian suplementasi isoflavon dapat menurunkan profil lipid melalui jalur regulasi Fatty Acid Syntase (FAS), hormone-sensitive lipase (HSL) yang secara langsung mempengaruhi metabolisme lipid. FAS merupakan enzim lipogenik yang berperan sentral terhadap lipogenesis dan merubah kalori diet menjadi energy cadangan. Inhibisi dari ekspresi gen FAS akan menyebabkan penurunan lemak tubuh. Penurunan regulasi FAS pada adiposit yang kemudian memberikan dampak penurunan lemak tubuh yang secara langsung berpengaruh pada profil lipid. HSL merupakan suatu lipase netral intraseluler yang berperan dalam metabolism lipid. Pemberian suplementasi isoflavon mampu meningkatkan ekspresi HSL, hal tersebut akan meningkatkan lipolisis di hepar yang kemudian akan meberikan efek penurunan berat badan yang secara langsung memberi dampak pada profil lipid. ${ }^{6}$

Reactive oxygen species (ROS) mampu menginisiasi peroksidase lipid dan kerusakan DNA yag menyebabkan suatu mutagenesis, karsinogenesis dan kematian sel, jika sistem antioxidant mengalami gangguan. Ketika dibentuk radikal bebas akan secara langsung menyerang struk sel tubuh, menyebabkan kerusakan mebran sel dan sistem enzim. Pemberian suplementasi isfolavon yang dapat bertindak sebagai protektif antioksidan faktor yang mengurangi pembentukan radikal bebas dan reaktif oksigen melalui dekomposisi hydrogen peroksidase tanpa mebentuk suatu radikal baru dan mengisolasi radikal bebas sebelum mencapai suatu sel target. Selain itu isovlaon memiliki struktur yang serupa dengan senyawa phenol yang mampu mendonasikan atom hydrogen yang kemudian mampu mengeruk radikal bebas. ${ }^{7}$ 
Pemberian suplementasi isoflavon juga berefek pada penurunan dari mediator inflamasi seperti TNF- $\alpha$ dan IL-6, yang merupakan dua mediator inflamasi kuat yang mampu meicu pembentukan antioksidan, meningkatkan ekspresi adhesion molecule yang menginisiasi penyakit kardiovaskular. Penurunan marker inflamasi yang disebabkan oleh isoflavon juga berpengaruh secara langsung terhadap penurunan dari profil lipid yang nantinya akan meberikan suatu efek protektif terhadap kejadian penyakit jantung coroner. ${ }^{8}$

Secara keseluruhan suplementasi isoflavon memberikan efek penurunan profil lipid melalui jalur penurunan pembentukan ROS dan pegaturan metabolism lipid. Pada penelitian ini suplementasi ekstrak rosela yang mengandung flavonoid mampu menurunkan kadar kolesterol total, trigliserida, kolesterol LDL, dan meningkatkan kolesterol HDL.

Penelitian oleh Chun-Sen (2003) mengenai efek pemberian isoflavone pada 3 dosis berbeda $240 \mathrm{mg}$, $480 \mathrm{mg}$, dan $1920 \mathrm{mg}$ terhadap perubahan glukosa plasma, profil lipid, dan aktivitas enzim antioksidan pada tikus diabetes. Penelitian ini menunjukkan terdapat suatu perbedaan yang bermakna setelah pemberian intervensi isoflavon terhadap kadar total kolesterol pada keempat kelompok intervensi, kelompo kontrol (203.7 \pm 83.3 ), isoflavon $240 \mathrm{mg}$ $(149.2 \pm 33.2)$, isoflavon $480 \mathrm{mg}(146.3 \pm 39.8)$ dan isoflavon $1920 \mathrm{mg}(101.8 \pm 10.8)$, serta suplementasi isoflavon pada dosis yang paling tinggi menimbulkan kadar kolesterol total yang paling rendah. Hal tersebut juga terjadi pada komponen kolesterol $\mathrm{LDL}$, dimana suplementasi isoflavon dosis tertinggi memberikan kadar kolesterol LDL yang paling rendah. Hasil tersebut merupakan hasil serupa dengan temuan peneliti, pemberian isoflavon dosis terbesar akan memberikan penurunan profil lipid yang lebih besar dibandingkan dengan dosis isoflavon yang lebih kecil. ${ }^{9}$

Penelitian lain oleh Mokhtar (2004) mengenai pemberian suplementasi isoflavon $2.5 \mathrm{mg} / \mathrm{kg} /$ hari dan $5 \mathrm{mg} / \mathrm{kg} /$ hari selama 13 minggu terhadap penurunan profil lipid pada kelinci. Pemberian suplementasi isoflavon mampu menurunkan LDL sejumlah $19 \%$ dan $22 \%$, menurunkan VLDL sejumlah $18 \%$ dan $23 \%$, menurunkan kolesterol total $16 \%$ dan $19 \%$, dan meningkatkan HDL hingga $29 \%$ dan 32\% $(\mathrm{p}<0.05)$ dibandingkan dengan kelompok kontrol. Selain hal tersebut suplementasi isoflavon memberikan penurunan radikal bebas di plasma, hepar, otak, testis, dan ginjal. Suplementasi isoflavon dengan dosis yang lebih besar $(5 \mathrm{mg} / \mathrm{kg} /$ hari) meberikan dampak penurunan profil lipid yang lebih besar. ${ }^{7}$

Studi lain oleh Zheng (2017) mengenai efek fitoesterogen dan olahraga pada profil lipid tikus wistar yang dilakukan oovorektomi. Suplementasi isoflavon $479 \mathrm{mg} / \mathrm{kg}$ diberikan setiap harinya, kemudian dilakukan perbandingan pada kelompok tikus yang mendapat ovorektomi _ latihan, tikus yang mendapat intevensi diet tinggi isoflavon. Studi ini menunjukka terdapat adanya penurunan kolesterol total dan peningkatan kolesterol HDL pada kelompok tikus yang mendapatkan diet tinggi isoflavon. ${ }^{10}$

Pada penelitian ini simvastatin memberikan efek perubahan yang terbaik, kemudian disusul oleh ekstrak rosela $300 \mathrm{mg} / \mathrm{kg} / \mathrm{hari}$. Ditinjau dari mekanisme kerja, simvastatin merupakan suatu lipid lowering drugs yang bertindak sebagai $H M G-C o A$ reductase inhibitors yang menyebabkan inhibisi dari enzim dan menyebabkan hambatan dari sintesis ubiquinone, dolichol, dan prenilasi protein yang penting dalam pembentukan lemak. Selain dari pada itu golongan statin meningkatkan reseptor LDL berafinitas tinggi yang kemudian meingkatkan laju fraksi katabolik dari LDL, ekstraksi oleh hepar prekursor LDL (sisa-sisa VLDL) yang ada dipembuluh darah yang menyebabkan penurunan dari LDL. Golongan statin memiliki efek toksisitas yang cukup banyak dalam penggunaan jangka panjang seperti hepatotoksisitas, nefrotoksisitas, dan rhabdomiolisis. ${ }^{11}$

Pada sisi lain antosianin yang merupakan gugus isoflavon menurunkan profil lipid melalui mekanisme antioksidan dan pengaturan regulasi lipid melalui pengaruhnya pada gen HSL dan FAS. Toksisitas dari suplementasi isoflavon yang masih belum diketahui. Waktu penggunaan, efek samping, dosis terapan sebagai terapi suplementasi masih menjadi suatu isu yang harus dikaji lebih lanjut. Melihat profil farmakologi dari isoflavon tersebut, sehingga ekstrak rosela memiliki potensi sebagai suplementasi tambahan (terapi adjuvant) sebagai agen hipolipidemia.

Adanya suatu keadaan dose dependent effect (efek yang bergantung pada dosis) yang menyebabkan suatu fenomena penggunaan dosis $300 \mathrm{mg} /$ $\mathrm{kg} / \mathrm{hari}$ memberikan efek penurunan profil lipid dibandingkan dengan suplementasi ekstrak rosela $200 \mathrm{mg} / \mathrm{kg} / \mathrm{hari}$, dan $100 \mathrm{mg} / \mathrm{kg} / \mathrm{hari}$.

\section{SIMPULAN}

Suplementasi ekstrak rosela dengan dosis $300 \mathrm{mg} /$ $\mathrm{kg} /$ hari memberikan penurunan total kolesterol, trigliserida, dan kolesterol LDL, dan peningkatan kolesterol HDL yang lebih tinggi dibandingkan dengan suplementasi ekstrak rosela $100 \mathrm{mg} / \mathrm{kg} /$ hari dan suplementasi ekstrakrosela $200 \mathrm{mg} / \mathrm{kg} /$ hari. Suplementasi ekstrak rosela dengan dosis 100 $\mathrm{mg} / \mathrm{kg} / \mathrm{hari}$ tidak memberikan perbedaan yang bermakna terhadap perbaikan profil lipid dibandingkan dengan kelompok kontrol yang mendapat 
aquadest. Perbaikan hasil profil lipid pada pemberian simvastatin $0.2 \mathrm{mg} / \mathrm{kg}$ masih lebih baik dibandingkan dengan ekstrak rosela $300 \mathrm{mg} / \mathrm{kg} / \mathrm{hari}$.

\section{DAFTAR PUSTAKA}

1. PERKENI. Panduan Pengelolaan Dislipidemia Panduan Pengelolaan Dislipidemia. 2015. PERKENI

2. Gosain S. Hypolipidemic effect of ethanolic extract from the leaves of Hibiscus sabdariffa L. in hyperlipidemic rats. Acta Poloniae Pharmaceutica - Drug Research, 2010;67(2):179-184.

3. Chairunnisa, N.H.,.Effectivity of roselle extract (Hibiscus sabdariffa linn.) as a treatment for hyperlypidemia. Jurnal Kedokteran Unila. 2015;4(4):67-69.

4. Nelson, R. H. (2014). Hyperlipidemia as a Risk Factor for Cardiovascular Disease Robert. Primary Care. 2014;40(1):195-211.

5. Sabzghabaee AM, Ataei E, Kelishadi R, Ghannadi A, Soltani R, Shirinsadat B, Shirani S. Effect of Hibiscus sabdariffa Calices on Dyslipidemia in Obese Adolescents: A Triple-masked Randomized Controlled Trial. Materia socio-medica. 2013;25(2):76-79.

6. Xiao-lin NA, Junko E, Fumie S, Hono BC, Yoshiko I. Isoflavone regulates lipid metabolism via expression of related genes in OVX rats Fed on high fat diet. Biomedical an environmental science. 2008;21:357-364.

7. Mokhtar IY, Kamel IK, Alshaima ME, Hoda HB. Antioxidant activities and lipid lowering effect of isoflavone in male rabbits. Food and chemical technology. 2004;42(1):1497-1503
8. Antonio C, Miguel AG, Juan J. Isoflavones and cardiovascular disease. Maturitas. 2010;67(4):219-226.

9. Chun SH, Wan CC, Sung LY. Effect of soy isoflavones supplementation on plasma glucose, lipids, and antioxidant enzyme activities in streptozotocin-induced diabetic rats. Nutrition research. 2003;23(2):67-65.

10. Zheng W, Jana R, Anja N, Kristina O, Sabine E, Kulling, Mingyoung X, Patrick D. Combinatory effect of phytoesterogen and exercise on body fat mass and lipid metabolism in ovariectomized female rats. Journal of steroid biochemistry and molecular biology. 2017;1(1):1-9

11. Harikumar K, Althaf SA, Kishore Kumar B, Ramunaik M, Suvarna C. A Review on Hyperlipidemic. Iternational Journal of Novel Trends in Pharmaceutical Sciences. 2013; 3(4):69-80.

12. Sutirtayasa IW, Jawi IM. Antioxidant potential and hypolipidemic effect of combined purples sweet potato (Ipomoea batatas L.) tuber extract with honey in rats given high cholesterol feed. 2017. Bali Med J;3(3):S65-S69.

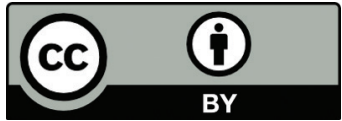

This work is licensed under a Creative Commons Attribution 